\title{
Redescription of the holotype of Larinia vara Kauri, 1950 (Aranei: Araneidae) from South Africa, with establishing of a new combination
}

\section{Переописание голотипа Larinia vara Kauri, 1950 (Aranei: Araneidae) из ЮАР, с установлением новой комбинаџии}

\author{
Yuri M. Marusik \\ Ю.М. Марусик
}

\begin{abstract}
Institute for Biological Problems of the North RAS, Portovaya Str. 18, Magadan, Russia. E-mail: yurmar@mail.ru Zoological Museum, Biodiversity Unit, FI-20014 University of Turku, Finland .

Department of Zoology \& Entomology, University of the Free State, Bloemfontein 9300, South Africa.

Институт биологических проблем Севера ДВО РАН, ул. Портовая 18, Магадан 685000, Россия.
\end{abstract}

KEY WORDS: Larinia, Mangorini, Araneini, Araneae, new combination, SAR, Transvaal, Kwazulu-Natal.

КЛЮЧЕВЫЕ СЛОВА: Larinia, Mangorini, Araneini, Araneae, новая комбинация, Южная Африка, Трансвааль, Квазулу-Наталь.

ABSTRACT. The holotype male of Larinia vara Kauri, 1950 known only from Kwazulu-Natal is redescribed. It was found that species does not belong to Larinia Simon, 1874 or any other genera of Mangorini. Judging from the somatic characters it is most close to Atea C.L. Koch, 1837, a genus currently considered as junior synonym of Araneus Clerk, 1757 sensu lato. Because of this a new combination Araneus varus (Kauri, 1950) comb.n. is suggested.

РЕЗЮМЕ. Переописан голотип Larinia vara Kauri, 1950, вида известного из Квазулу-Наталь. Было установлено, что вид не принадлежит роду Larinia Simon, 1874 и ни к одному из родов Mangorini. Судя по соматическим признакам вид наиболее близок к Atea C.L. Koch, 1837, роду считающимся младшим синонимом Araneus Clerk, 1757 sensu lato. Предложена новая комбинация Araneus varus (Kauri, 1950) comb.n.

\section{Introduction}

Larinia Simon, 1874 and related genera are relatively well studied in the Old World and particularly in Africa due to series of revisions made by Grasshoff [1970a-c, 1971]. He examined all species listed in Larinia in catalogues written by Bonnet [1957] and Roewer [1942]. Most of species were transferred to other genera of the tribe Mangorini Simon, 1895. One species, Larinia vara Kauri, 1950 from South Africa, described in the period not surveyed in the catalogs was overlooked by Grasshoff [1970]. Recently I had an opportunity to study the holotype of this species and recognized that it does not belong to Larinia or Mangorini at whole, but being a member of Araneini. Search of literature for Araneini occurring in South Africa reveals only two genera, Araneus Clerck, 1757 and Pararaneus Caporiacco, 1940. The latter one is well studied due to the revision of Grasshoff [1968] but Araneus was found to be very poorly studied in South Africa. Of 12 species of Araneus reported from South Africa [Platnick, 2014], all are known by single sex, seven by females, two by males and two by juveniles. Only one species description, Araneus coccinella Pocock, 1898, has any illustration. Because of this I was unable to check if Larinia vara can be conspecific with any species considered in Araneus from South Africa. The goal of this paper is to redescribed the holotype of Larinia vara and establish new combination.

\section{Material and methods}

Specimens were photographed using an Olympus Camedia E-520 camera attached to an Olympus SZX16 stereomicroscope at the Zoological Museum, University of Turku. Abbreviations used for spination and leg segments are as follows: $\mathrm{d}$ - dorsal, $\mathrm{Fe}$ - femur, $\mathrm{Me}$ - metatarsus, $\mathrm{Pa}$ patella, $\mathrm{p}$ - prolateral, $\mathrm{r}$ - retrolateral, Ta - tarsus, $\mathrm{Ti}$ tibia, v - ventral. All measurements are given in millimeters. Leg measurements is given in the following sequence: total (femur + patella + tibia + metatarsus + tarsus).

\section{Taxonomy}

Araneus varus (Kauri, 1950) comb.n. Figs 1-7.

Larinia vara Kauri, 1950: 9, f. $7\left(\sigma^{7}\right)$.

MATERIAL EXAMINED: Holotype $\sigma^{7}$ (type No 199:1, Reg. no L948/3296), South Africa, Transvaal: Pietermaritzburg, Town Bush, 27.10.1948 (Bertil Hanström). 

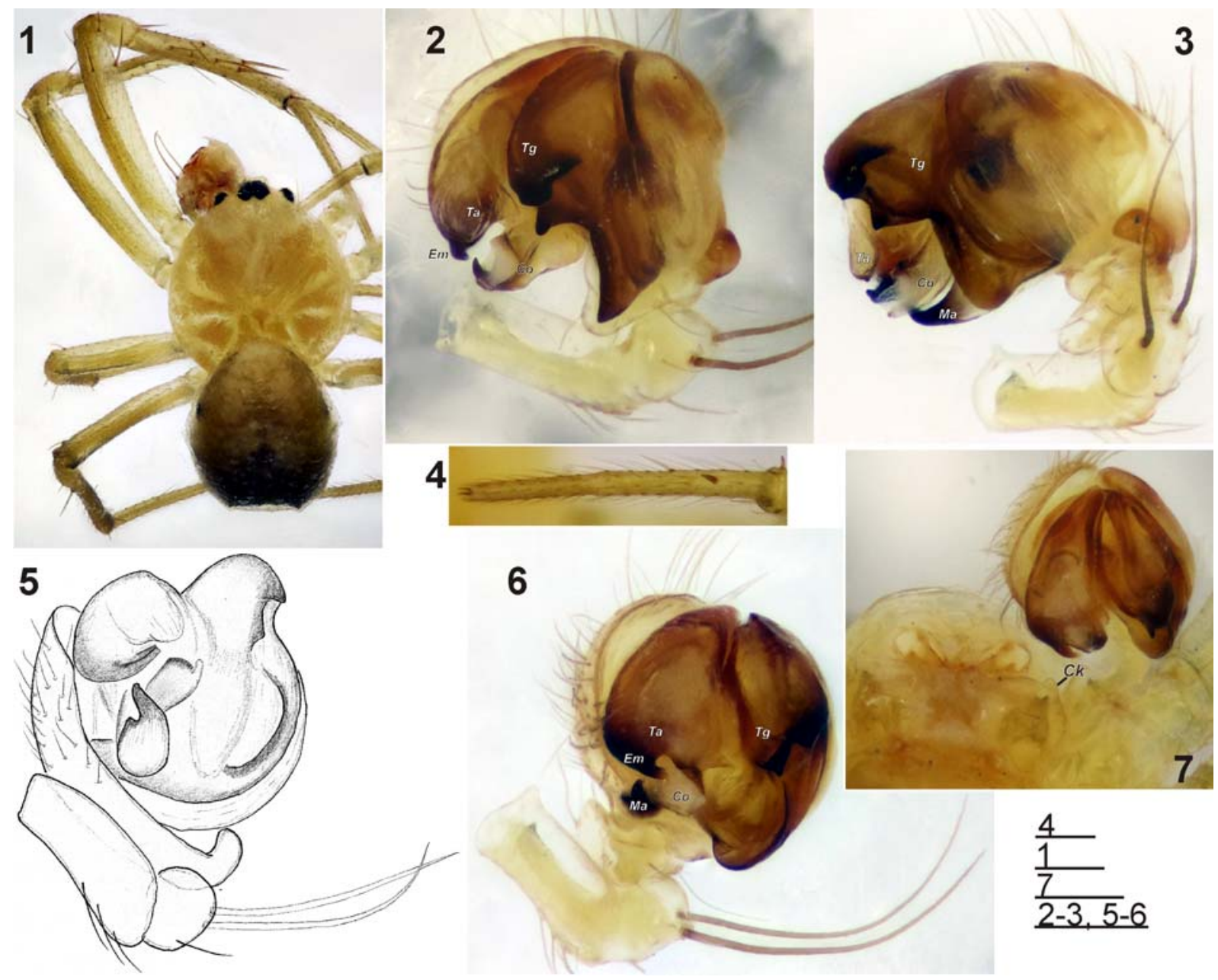

Fig. 1-7. Habitus and palp of the holotype male of Larinia vara. 1 - habitus, dorsal; 2-3 - palp, retrolateral and ventro-retrolateral; 4 - metatarsus and tarsus III, dorsal; 5-6 - palp, ventral and anterior-ventral; 7 - mouth parts and palp, ventral. Scale: $1-0.5 \mathrm{~mm}, 2-$ $7-0.2 \mathrm{~mm}$. Abbreviations: $\mathrm{Ck}$ - coxal knob, $\mathrm{Co}$ - conductor, $\mathrm{Em}$ - embolus, $\mathrm{Ma}$ - median apophysis, $\mathrm{Ta}$ - terminal apophysis, $\mathrm{Tg}$ - tegulum.

Рис. 1-7. Внешний вид и пальпа самца голотипа Larinia vara. 1 - габитус. сверху; 2-3 - пальпа, ретролатерально и вентроретролатерально; 4 - предлапка и лапка III, сверху; 5-6 - пальпа, снизу и спереди-снизу; 7 - ротовой аппарат и пальпа, снизу. Масштаб: $1-0,5$ мм, 2-7 - 0,2 мм. Сокращения: $C k-$ выступ тазика, $C o-$ кондуктор, $E m-$ эмболюс, $M a-$ медальный апофиз, $T a$ - терминальный апофиз, $T g$ - тегулум.

NOTE. While describing in detail this species, Kauri [1950] did not provide the size of the holotype. Currently Town Bush is suburb of Pietermaritzburg and belongs to Kwazulu-Natal Province.

DESCRIPTION. Total length 2.75. Carapace 1.5 long, 1.35 wide. Carapace, sternum and legs without pattern (Fig. 1), probably due to bleaching. Palpal coxa with small lateral knob $(C k)$ directed anteriorly (Fig. 7). Coxa I and II not modified. Leg I modified (Fig. 1): tibia with 8 strong spines on prolateral side, proventral spines arranged in one row. Metatarsus III with short and strong dorsal subapical spine (Fig. 4) Spines on metatarsus IV weakly developed. Leg measurements: I $5.31(1.63+0.58+1.35+1.15+0.6)$, II $4.84(1.53+$ $0.5+1.2+1.03+0.58)$, III $3.21(1.1+0.35+0.65+$ $0.68+0.43)$, IV $4.51(1.5+0.43+1.05+1.0+0.53)$
Legs spination: I: Fe 1d 2p 1r, Pt 1d 1r, Ti 1d 2p 1r 6pv 3pv; II: Fe 1d 1p, Pt 1d, Ti 1d 3pv 2rv; III: Fe 1p, Pa 1d, Ti $2 \mathrm{~d}$ or $3 \mathrm{~d} 2 \mathrm{p} 2 \mathrm{pv}$ 1rv, Mt 1d 2p 1r; IV: Fe 1p, Pt 1d, Ti 1d 1p 2pv 1rv, Mt 1p 1pv.

Palp as in Figs 2-3, 5-7. Patella with 2 very long macrosetae, macrosetae longer than cymbium and femur; tegulum $(T g)$ large and complex, with 3 processes and strong ridge; median apophysis $(\mathrm{Ma})$ longitudinal, with 2 anterior tips; conductor $(C o)$ weakly sclerotized with finger-shaped process (Fig. 5); terminal apophysis ( Ta ) membranous, wide; embolus ( $E m$ ) massif, its free part short.

COMMENTS. Leg I modification this species is similar to Atea C.L. Koch, 1837, a genus currently considered as a junior synonym of Araneus. In males of Araneus s.str., leg II is modified and bears strong 
spines. Coxal modification (hook on coxa I and depression on coxa II) known in most of Araneus s.str. (cf. Levi, 1971; Šestaková et al., 2009) is absent in $A$. varus, like in all members of Atea.

ACKNOWLEDGEMENTS. I thank Maria Mostadius (Lund University Sweden) for sending me the holotype male redescribed here and Seppo Koponen (University of Turku) for allowing me to use museum's facilities. English of the earlier draft was kindly checked by Robb Bennett (Royal British Columbia Museum, Canada). Robert J. Kallal, Gustavo Hormiga and an anonymous reviewer provided comments on an earlier version of this paper.

\section{References}

Bonnet P. 1955. Bibliographia araneorum. Toulouse. T.2. Pt.1. P.1-918.

Grasshoff M. 1968 Morphologische Kriterien als Ausdruck von Artgrenzen bei Radnetzspinnen der Subfamilie Araneinae (Arachnida: Araneae: Araneidae) // Abhandlungen der Senckenbergischen Naturforschenden Gesellschaft. Bd.516. S.1-100.

Grasshoff M. 1970a. Die Gattung Kilima n. gen. (Arachnida: Araneae: Araneidae) // Senckenbergina biologica. Bd.51. S.119128.
Grasshoff M. 1970b. Die Tribus Mangorini. I. Die Gattungen Eustala, Larinia s. str., Larinopa n. gen. (Arachnida: Araneae: Araneidae-Araneinae) // Senckenbergina biologica. Bd.51. S.209-234.

Grasshoff M. 1970c. Die Tribus Mangorini. II. Die neuen Gattungen Siwa, Paralarinia, Faradja, Mahembea und Lariniaria (Arachnida: Araneae: Araneidae-Araneinae) // Senckenbergiana biologica. Bd.51. S.409-423.

Grasshoff M. 1971. Die Tribus Mangorini, III. Die Gattung Drexelia MacCook (Arachnida: Araneae: Araneidae-Araneinae) // Senckenbergiana biologica. Bd.52. S.81-95.

Kauri H. 1950. On some South African spiders and harvest-spiders // Kungliga Fysiografiska Sällskapets i Lund Förhandlingar. Vol.20. N.6. P.1-16.

Levi H.W. 1971. The diadematus group of the orb-weaver genus Araneus north of Mexico (Araneae: Araneidae) // Bulletin of the Museum of Comparative Zoology at Harvard College. Vol.141. P.131-179.

Platnick N.I. 2014. The World Spider Catalog. Version 15. American Museum of Natural History. Available from: http:// research.amnh.org/entomology/spiders/catalog/ (accessed 15 March 2017).

Roewer C.F. 1942. Katalog der Araneae von 1758 bis 1940. Bremen. Bd.1. S.1-1040.

Šestáková A., Krumpál M., Krumpálová Z. 2009. Araneidae (Araneae) Strednej Európy: I. Rod Araneus. Prírodovedecká Fakulta Univerzity Komenskéhó, Bratislava. 151 pp.

Responsible editor: K.G. Mikhailov 